\title{
Jews and Judaism in Norway today
}

\author{
Tyson Herberger
}

AвSTRACt - This address was given as part of a podium discussion on Judaism in Norway today held at the Jewish Museum in Oslo on 4 March 2018. Other participants in the panel were Rabbi Lynn Feinberg (Jewish Renewal movement), Rabbi Joav Melchior (Orthodox movement, current rabbi of Det Mosaiske Trossamfund in Oslo), Rabbi Shaul Wilhelm (Chabad shaliach in Oslo) and Professor Catherine Hezser (SOAS, London, and University of Oslo) as chair. The comments argue that Judaism in Norway is diverse and relatively unknown, with a majority of Jews in Norway probably being uncounted in current population estimates. As such there is no single experience of Norwegian Jewish identity.

\section{Introduction}

This short essay emerges from a panel discussion of four rabbis living or working in Norway, organised by the University of Oslo's Faculty of Theology on 4 March 2018 at the Jewish Museum of Oslo as part of the workshop 'The Jewish Tradition - Does it Matter?' This article presents the views of one participant, the author, in response to questions drafted by Professor Diana Edelman (University of Oslo) and then posed by the panel moderator, Professor Catherine Hezser (SOAS, London, and University of Oslo). Following the order of the initial event, this essay first addresses demographics, where it argues that the Jewish population is larger than is generally conceived and that little is known about the Jews in Norway. Then it turns to the topic of Jewish identities in Norway, where it argues that Norway is home to a diverse array of Jewish identities and practices both in and outside of the established communities of Det Mosaiske Trossamfund in Oslo (hereafter DMT) and Det Jødiske Samfunn in Trondheim (hereafter DJST). On the final question of how to create a higher profile of Jews and Judaism in Norway, it discusses Jewish studies and religious education textbooks in Norway.

\section{Jewish demographics in Norway}

The demographics of Jewish Norway are largely unknown. Neither Statistics Norway nor other sources track Jewish demographic data. Only membership of the official communities is tracked. This leaves us somewhat clueless as to those Jews who are unaffiliated, or affiliate via alternates to the main communities via Chabad, the Jewish Museum of Oslo, with earlier progressive Jewish groups, or with any other Jewish circles beyond DMT or DJST.

Yet there are clues that Norway's Jewish population is much larger than Statistics Norway's official figure of 769 members of DMT and DJST (Bolsgård 20I7). There are I 89 I Israelis, and children and grandchildren of Israelis, registered as living in Norway (Steinkellner and Dzamarija 2018), and it seems plausible that at least half of them are likely to have an (at least partially) Jewish identity. With 63,3 I 9 people in Norway registered as having an American background (ibid.), and somewhere between I.75 per cent (DellaPergola 2016: 3 I4) and 3.8 per cent (Lugo et al. 2013: 24) of America identifying as Jewish, one cannot help but think that a few hundred (or perhaps even a few thousand) of the Norwegians with 
American background may also have a Jewish background. The American and Israeli populations in Norway alone are likely to include more Jews than are registered in the officially recognised communities, and many of them are not members of the communities, in part because their Jewishness may not be enough for communal membership.

DMT requires one to be a Jew according to Orthodox Jewish norms, which require a Jewish mother or an acceptable halachic conversion to be recognised as a Jew. Presumably, not all of those with a Jewish identity based upon ancestry (or any other claim) will fulfil these criteria as it could be they are Jewish from the father's side and not the mother's. However, being of patrilineal Jewish descent does not automatically deny the possibility of being Jewish. There are actually multiple essentialist definitions of who is a Jew, and several non-orthodox definitions allow for patrilineal descent. For example, as early as i96I portions of Reform Judaism accepted children of non-Jewish mothers and Jewish fathers raised Jewishly as Jews (CCAR I961). Their acceptance was widened with a I983 Reform decision to accept as Jews those who were not raised Jewish but rather claim their Jewishness in adulthood (CCAR r 983, see final paragraph). Whether adopted children are considered Jewish without conversion also varies in essentialist constructs of who is a Jew. Non-essentialist Jewish identities are also plausible, and the shift away from essentialist identity need not be understood as being exclusively opposed by those in orthodoxy. The Orthodox scholar Erik Cohen of Orthodox Judaism's flagship Bar Ilan University wrote 'Ascribed, inherited, and primordial identities are gradually being supplanted by achieved, voluntarily chosen, and constructed identities. Choice in the realm of identity becomes not only possible but mandatory' (Cohen 2010: IO).

Regarding marriages and moving, it seems that the vast majority of Norwegian Jews marry
non-Jews, as one would expect for a small community in a highly secularised society. However, endogamous marriages also occur. Usually they involve a non-Norwegian Jewish partner, and the couple then must decide whether they will build their home in Norway or elsewhere. It seems not uncommon for young Jews to move to larger centres of Jewish life (Israel, London, New York or elsewhere). Some later return to Norway. On the flip side, there are non-Norwegian Jews who move to Norway for work, study, love or the Nordic model of life and end up staying. Without data it is hard to know if more Jews are coming or going, but my impression is that there is a net influx of Jews to Norway, but that most of these Jewish newcomers have not affiliated with the official communities in Oslo or Trondheim.

In sum, Norway's Jewish population is not by any means limited to the membership of the DMT and DJST, imported Jewish spouses or immigrants from the US and Israel. There are other Norwegian-born Jews as well as other immigrant Jews. Thus the total Jewish population of Norway is probably several times the commonly stated estimates of I400-2000, but it is hard, if not impossible, to say exactly how large it is (Herberger 2018).

\section{Jewish identities in Norway}

For those who trace active family engagement in the Jewish community from pre-WWII Norway, it appears that their Jewish and Norwegian identities have often blended together into a more unified identity. A few examples include how some view skiing on wintry Sundays as one of the ideal forms of bliss. Going to the family bytte (cabin) for Pesach is always an option. For many, matza is naturally eaten with brunost (Norwegian brown cheese). I 7 May (Norway's constitution day) is started with a visit to Henrik Wergeland's grave (a nineteenth-century Norwegian poet who campaigned to allow 


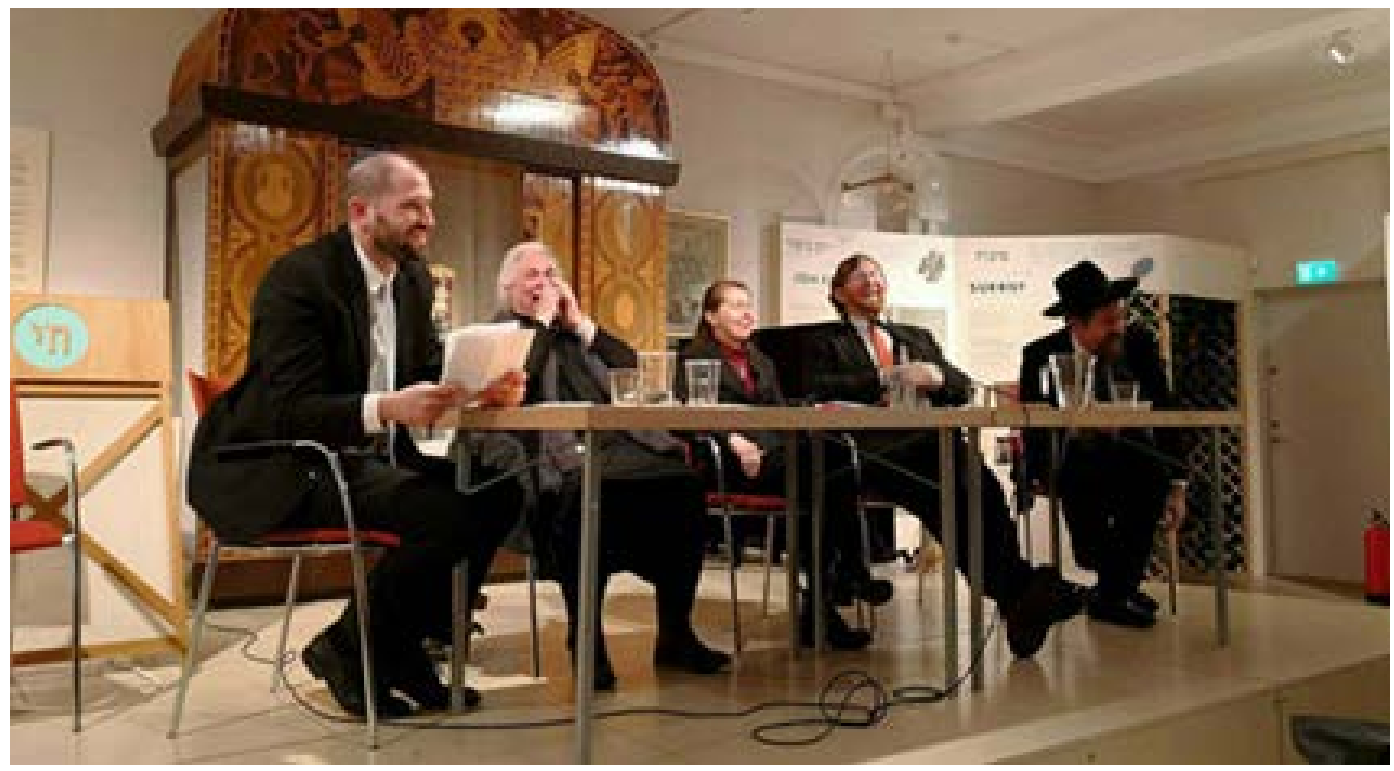

Podium discussion on Jews and Judaism in Norway today with (left to right) Rabbi Melchior, Rabbi Feinberg, Professor Hezser, Rabbi Herberger, and Rabbi Wilhelm. Photo: Janne Noëmi Skogtvedt.

Jews into Norway). A few have even converted the Norwegian Christian tradition of seven types of Christmas biscuits to seven types of Chanuka sweets.

Those with a Jewish immigrant parent and a Norwegian non-Jewish parent are more likely to have a more bifurcated identity, with a Jewish half and a Norwegian half. This is especially to be expected in cases where they are not engaged in Norwegian Jewish activities or institutions. None of this person's Jewish family is Norwegian, and excluding their immediate family, the Jewish relatives do not live in Norway. Meanwhile all of their Norwegian family are non-Jews. This sets a model wherein Jewish life exists more strongly outside Norway. Additionally, their Norwegian family not only do not follow Jewish practices, but they most likely have Christian identities, whether secular or religious, and follow relevant Christian (religious or secular) practices. In some cases, Norwegian is not even the main language spoken at home, the primary locale of Jewish practice and engagement, thus further pushing Jewish identity outside their Norwegian headspace and into the foreign headspace.
Those who are themselves immigrants often have an even harder time constructing a Norwegian Jewish identity as they have already been socialised to a non-Norwegian Jewish identity and a general non-Norwegian national identity.

Of course, the above is an exaggeration to draw a possible picture that is the reality for some but certainly not universal. Many of those who immigrate themselves or with mixed families go on to acquire active and integrated Norwegian Jewish identities, with some immigrant Jews even serving as employees or board members of the established communities (which may or may not be the same as acquiring a Norwegian Jewish identity). Communal Jewish infrastructures (formal or informal, through the official communities, ad hoc Facebook groups, or otherwise) can provide networks for integrating the two identities. The Pierre Gildesgame Tournament (a Scandinavian Jewish football tournament), previously the Bnei Akiva youth movement, Bnai Brith men's lodge, the annual congresses of the SJUF (the Scandinavian Jewish Youth Organization), speeches at the Jewish Museum and numerous other events can 
integrate even those who are not engaged in synagogue life into a Norwegian Jewish milieu and assist in an integrated identity formation.

For many of the Jews in Norway, especially those with an Israeli background, Israel is a large part of their Jewish identity and life. Hebrew is the second language of synagogue announcements at DMT and the primary language for many of the regular attendees at community events. Prayers are said weekly for the state of Israel and IDF soldiers. There are post-high school trips to Israel (previously just Israel, now the gap year programme is split between Israel, America and Norway). Some choose to spend additional time in Israel as volunteers, students or even in the military. Israeli musicians are regularly in town, and some Jews make a point of frequenting their concerts. Israeli sports can also be a draw, not only online, but also when Israeli football teams play in Norway, such as HaPoel Eshkol competing several years in the Norway Cup (purportedly the world's largest youth football tournament), or the occasional professional matches such as the Sarpsborg-Maccabi Tel Aviv matches in August 2018. Others are engaged in pro-Israel politics and there are often a few Jews to be found at events organised by Med Israel for Fred (With Israel for Peace, a Norwegian member-based pro-Israel orgnisation).

Looking at religious identities, some of Norway's Jews identify via non-orthodox religious options while others self-identify as traditional and want Orthodox Judaism even if they themselves are not observant according to the traditional Orthodox framework. Some Jews, though very few, in Norway try to keep kosher and shabbat fully, following traditional understandings of halacha, while many may try to observe portions thereof, or do so in the house but not out of the house.

Chabad appears to be the largest organised Jewish religious actor in Norway outside the established communities. They draw in many Israeli Jews, but alongside them Jews of every background. Hundreds attend the annual Rosh Hashana and Pesach dinners arranged by Chabad, as well as other large events such as the hachnasat sefer torab (induction of a new Torah scroll) in August 20 16. Chabad plans to open a permanent Chabad House on Josefines gate in Oslo in the coming year or two, and expects to increase their offerings and activities once in the dedicated facility.

There is also an attempt (or perhaps multiple attempts) to (re-)establish non-Orthodox communal prayer options in Oslo. Already in the twenty-first century, the Foreningen Progressiv Jødedom i Norge (Association for Progressive Judaism in Norway) has both formed and become defunct. At their peak they received support from the Oslo municipality and met fortnightly with religious and cultural activities. Norwegian-born Rabbi Lynne Feinberg previously led a group that met occasionally for prayers and learning, and she still leads occasional events such as Friday-night prayers at Oslo's Jewish Museum on Oslo kulturnatt (Oslo Culture Night) in 201 7. The most frequent communal non-orthodox prayer option active at the moment is the Library Havura, which started in February 2018. It holds progressive services in the library of Det Mosaiske Trossamfunn in Oslo on Saturday afternoons approximately monthly. An array of DMT members and non-members participate. In Trondheim there is talk over whether the community should maintain an Orthodox identity.

Not all Jews in Norway identify religiously no matter what the denomination, with some preferring to engage in cultural or other expressions of Judaism. The Jewish museums in both Oslo and Trondheim as well as the HL-Senteret (Norwegian Centre for Studies of the Holocaust and Religious Minorities, in Oslo) host various lectures and other activities which draw in a significant Jewish audience. Trondheim is also home to an annual Jewish cultural festival, and even a 
klezmer band. Oslo is home to a Jewish film festival. Sporting events can draw some Jews out, and in addition to the aforementioned Israeli sports draws, Jews in Norway also gather to compete in football tournaments, go skiing and do other sports together in Norway and elsewhere through Maccabi and other organisations.

In sum, this author believes there is no single experience of Norwegian Jewish identity, but rather multiple different forms of Norwegian Jewish identities.

\section{Raising the profile of Jews and Judaism in Norway via academia}

Perhaps surprisingly to an outsider, Jewish studies and Judaics are barely present as topics in Norwegian academia. While there has been an increase in Jewish studies in recent years, there is still only one full-time Jewish studies professor in the entire country (Gabriel Levy at the Norwegian University of Science and Technology in Trondheim, and even his position is officially in the science of religion and not Jewish studies). Having more would allow not only for better knowledge of Norway's Jews, but also for greater Jewish education for everyone from Norwegian school teachers and medical practitioners to academics and politicians. Beyond studying the primary 'other' of Europe's (and Western Christianity's) last thousand years, it makes sense that those studying to be priests should study both ancient and modern Judaism, as Christianity grew out of Judaism and then developed alongside it. One cannot fully understand Christianity or even European culture without some notion of Judaism. There should be funding for Jewish studies and Judaics positions in Norwegian academia.

Fortunately, the last few years has seen tremendous growth in research on Norwegian Jewry. At the doctoral level and higher, much of that focuses in one way or another on the shoah (the holocaust) and/or antisemitism. University research projects in Norway are often driven by budgetary considerations, and government grants to investigate these subjects have been the main drivers in the field. A few current examples of government-funded projects at the HL-Senteret (the institution most engaged in researching Jewish life in Norway today) are the 20I 5-i 9 project "The Image of "the Jew" in Contemporary Norway', and the 201 7-2 I project 'Shifting Boundaries: Definitions, Expressions and Consequences of Antisemitism in Contemporary Norway'.

A third project, in 20I7-2 I, 'Negotiating Jewish Identity: Jewish Life in twenty-first-century Norway', seems to take a step away from the shoah and antisemitism, judginb by the title alone. However, the project description lists antisemitism first amongst factors that have changed Jewish life in the last few decades so as to warrant the project, and further states that 'the Holocaust is a powerful backdrop' to the project (HL Senteret 20I7). Additionally, even this project is paid for with funds dedicated in the Norwegian government's 2016-20 action plan against antisemitism.

It is worth emphasising that the central role of research on the shoah and antisemitism in Norwegian Jewish studies is a product of public discourse, especially as represented by how government funding is directed, and it is not necessarily a product of the research interests of researchers or their institutions. Undoubtedly many, if not all, of my colleagues in Jewish studies in Norway would join me in calling for more funds to study Jews and Judaism in Norway without the prerequisite of inquiry into antisemitism or the holocaust. This is not to say the research being conducted is not valuable. It is. But not all Norwegian Jewish life revolves around memories and realities of murder, exile and hatred; and such a focus means we miss out on investigating what Jewish life in Norway lives for as opposed to what they live despite of. There is even an argument to be made that the 
current system furthers the othering of Jews by highlighting Jews as the object of scorn rather than highlighting Jews as themselves.

If we were to have more positions dedicated to researching Jews and Judaism in Norway, not only could we better create the reality described in the first paragraph of this section, but we could also provide for a more diverse and accurate portrayal of Judaism and Jewish Norway in textbooks for religious education. Some of the books work to include a lived religion perspective, but without adequate research, little is known upon which to base the books, and they often provide essentialist calls for what Judaism should be according to certain Orthodox constructs despite their being other essentialist notions as well as lived Jewish lives that differ from (and at times oppose) these statements. Work is being done on this, but progress takes time and depends not only on available research but also on private book publishers. Anders Aschim and I are analysing the presentation of Jews and Judaism in several of the middle-school religion textbooks in use in Norway, and expect to write on this topic in 2019 with a focus on the implications of the essentialist aspects of how these books portray Jews and Judaism.

\section{Conclusion}

In summary, this author believes Norwegian Jewry is more populous, more diverse, and less well known than is often presumed. As such, the author calls for a de-essentialising of who is Jewish, what is Jewish, and what is Judaism. One way to assist in doing that is to allocate funding for more research on Jews and Judaisms in Norway without the requirement that it be contingent upon seeing how the shoah or antisemitism play out in Jewish life. Obviously this is likely still to include the shoah or antisemitism, but the author calls for them to arise organically in the research rather than to be the lens through which the research is conducted.
Finally, the author wishes to thank Professor Diana Edelman (University of Oslo) for arranging and inviting him to participate in the podium discussion 'Jews and Judaism in Norway Today' as part of the the workshop 'The Jewish Tradition - Does it Matter?' organised by the University of Oslo's Faculty of Theology. Further thanks are due my co-panelists Rabbi Lynn Feinberg (Jewish Renewal movement), Rabbi Joav Melchior (Orthodox movement, current rabbi of Det Mosaiske Trossamfund in Oslo), Rabbi Shaul Wilhelm (Chabad shaliach in Oslo) and our chair Professor Catherine Hezser (SOAS, London and University of Oslo). Docent Ruth Illman (Åbo Akademi University) also deserves thanks for encouraging me to write up my comments from the discussion for publication.

Tyson Herberger is doctoral researcher in Religious Education at Norway Inland University of Applied Science. His research project has two aims: 1. to discuss how Jews and Judaism are presented in Norwegian RE textbooks, and 2. to learn how Jews in Norway who are not part of the recognized communities construct and live out their Jewish identities. Tyson is a modern orthodox rabbi whose last full-time pulpit was to serve as the Chief Rabbi of Wroclaw and Lower Silesia. He has published dozens of articles on Jewish topics as a congregational rabbi, several of which are in Chidusz, a Polish language periodical he co-founded.

\section{Bibliography}

Bolsgård, Øyvind, 20I 7. Trus- og livssynssamfunn utanfor Den norske kyrkja (Oslo, Statistisk

Sentrabyrå), <https://www.ssb.no/trosamf/>

CCAR (Central Conference of American

Rabbis), i96r. Rabbi's Manual (New York, CCAR)

I 983 . Report of the Committee on Patrilineal Descent on the Status of Children of Mixed Marriages, CCAR Responsa, <https://www. ccarnet.org/ccar-responsa/arr-appendix/> 
Cohen, Erik H, 2o Io. 'Jewish identity research: a state of the art', International Journal of Jewish Education Research, I(I), pp. 7-48

DellaPergola, Sergio, 2016. 'World Jewish Population, 201 6', The American Jewish Year Book, 201 6, vol. I i 6, ed. Arnold Dashefsky and Ira M. Sheskin (Drodrecht, Springer), pp. 253-332, <http://www.jewishdatabank. org/Studies/downloadFile.cfm?FileID=3584>

Herberger, Tyson, 201 8. 'Expanding estimates of Norway's Jewish population', paper presented at The Jews, Roma and the Nordic Countries: Current Research, New Perspectives Seminar, University College London, 6-7 September

HL-Senteret, 20 I7. 'Two new research projects: on antisemitism in contemporary Norway and Jewish life and identity' (Oslo), <https://www. hlsenteret.no/aktuelt/20 $7 /$ the-researchcouncil-of-norway-has-allocated-tworesearch-projects-to-the-center-for-studiesof-the-holocaust-and-religious-minorities. pdf>

Lugo, Luis, Alan Cooperman, Gregory Smith, Conrad Hackett, Cary Funk, and Neha Sahgal, 201 3. A Portrait of Jewish Americans (Washington DC, Pew Research Center), $<$ http://assets.pewresearch.org/wp-content/ uploads/sites/r I/20 I3/ro/jewish-americanfull-report-for-web.pdf>

Steinkellner, Alice, and Minja Tea Dzamarija, 20 I 8. Innvandrere og norskfødte med innvandrerforeldre, etter landbakgrunn. 1. januar (Oslo, Statistics Norway), <https:// www.ssb.no/befolkning/statistikker/innvbef> 